\title{
Nutritional evaluation of the germ meal and its protein isolate obtained from the carob seed (Ceratonia siliqua) in the rat
}

\author{
BY N. J. DROULISCOS AND VASILIKI MALEFAKI \\ Department of Biology, Nuclear Research Centre Democritos Aghia Paraskevi Attiki, Greece
}

(Received 31 January 1979 - Accepted 20 June 1979)

\begin{abstract}
I. Evaluation of the germ meal (CGM) of carob seed (Ceratonia siliqua) and its protein isolate was carried out with weanling rats. Comparisons were made with casein, soya-bean meal, whole defatted egg and a soya-bean protein isolate (Promine-D) as protein sources. The growth-promoting effects and certain biological indices were evaluated using the protein efficiency ratio (PER), biological value (BV) and net protein utilization (NPU) bioassay procedures.

2. The unsupplemented CGM had a PER of $1.66 \pm 0.09$ and an NPU of $0.58 \pm 0.013$. Addition of DLmethionine at 4,8 and $12 \mathrm{~g} / \mathrm{kg}$ diet resulted in a PER of $I \cdot 95 \pm 0.11,2 \cdot 01 \pm 0.11$ and $I \cdot 90 \pm 0.1 \mathrm{I}$ respectively. The corresponding BV values were $0.80 \pm 0.003,0.78 \pm 0.015$ and $0.74 \pm 0.011$, and those for NPU $0.69 \pm 0.013$, $0.66 \pm 0.026$ and $0.63 \pm 0.020$ respectively. The addition of amino acids improved the PER (2.24-2.59), BV $(0.78-0.79)$ and NPU $(0.71-0.73)$ values.

3. The BV and NPU assays for the unsupplemented carob germ isolate were low (BV $0.36 \pm 0.016$, NPU $0.35 \pm 0.015)$. Supplementation with amino acids resulted in a positive increase with values of $0.66 \pm 0.013$ and $0.64 \pm 0.013$ for BV and NPU respectively.
\end{abstract}

The nutritional potential of certain agricultural by-products has not been adequately studied, a fact that limits their utilization as animal food ingredients. The shortage and high prices paid for protein concentrates in livestock feeding has stimulated nutritional and economic feasibility studies of by-products and wastes as sources of protein. It appears therefore that the resources in such products need to be further exploited and thoroughly evaluated nutritionally.

Carob germ meal (CGM) is a by-product obtained from the germ of the carob seed (Ceratonia siliqua) after the separation of gums and the fibrous coating of the seed. The milled germ has a uniform consistency and is a light greyish colour. It provides in the dry state as fed, approximately $955 \mathrm{~g}$ dry matter and $426 \mathrm{~g}$ crude protein (nitrogen $\times 6 \cdot 25$ ) $/ \mathrm{kg}$. The current annual production of this by-product in Greece is approximately $2000 \mathrm{t}$ and is likely to increase.

The literature contains only one report by Ferreira (I964) of the evaluation of CGM protein. The CP content varies from 488 to $507 \mathrm{~g} / \mathrm{kg}$ and biological indices (biological value (BV) $0.5 \mathrm{I}$, protein efficiency ratio (PER) $\mathrm{I} \cdot 20$ ) have been reported for the rat.

In the present study well-established rat bioassay procedures were used to assess protein quality and obtain information on the nutritional value of CGM. An attempt has also been made to prepare a protein isolate from the CGM and evaluate in a comparative study its performance in the rat. The biological indices measured were BV, net protein utilization (NPU), PER and growth response of the rats to different levels of amino acid supplementation.

\section{EXPERIMENTAL}

Analytical procedures

Standard methods for moisture, CP, diethyl ether extract, crude fibre and ash were those described by the Association of Official Analytical Chemists (1970). Gross energy was determined in an adiabatic bomb calorimeter (Gallenkamp Co.). Total phenolic compounds 
Table I. Composition of carob (Ceratonia siliqua) germ meal (CGM)* and CGM protein isolate

(Mean values of two determinations)

\begin{tabular}{|c|c|c|}
\hline Analytical composition & CGM $(\mathrm{g} / \mathrm{kg})$ & CGM protein isolate $(\mathrm{g} / \mathrm{kg})$ \\
\hline $\begin{array}{l}\text { Moisture } \\
\text { Total nitrogen } \\
\text { Diethyl ether extract } \\
\text { Crude fibre } \\
\text { N-free extract } \\
\text { Total ash } \\
\text { Total energy }(\mathrm{MJ} / \mathrm{kg}) \\
\text { Total phenolic compounds }\end{array}$ & $\begin{array}{r}45 \cdot 0 \\
68 \cdot 2 \\
56 \cdot 6 \\
49 \cdot 9 \\
374 \cdot 6 \\
47 \cdot 7 \\
18 \cdot 8 \\
4 \cdot 3\end{array}$ & $\begin{array}{r}14 \cdot 0 \\
141 \cdot 9 \\
- \\
- \\
- \\
19 \cdot 8 \\
3.0\end{array}$ \\
\hline \multicolumn{3}{|l|}{ Amino acid profile $(\mathrm{g} / 16 \mathrm{~g} \mathrm{~N})$} \\
\hline $\begin{array}{l}\text { Aspartic acid } \\
\text { Threonine } \\
\text { Serine } \\
\text { Glutamic acid } \\
\text { Proline } \\
\text { Glycine } \\
\text { Alanine } \\
\text { Valine } \\
\text { Isoleucine } \\
\text { Leucine } \\
\text { Tyrosine } \\
\text { Phenylalanine } \\
\text { Lysine } \\
\text { Histidine }\end{array}$ & $\begin{array}{r}7 \cdot 47 \\
3 \cdot 16 \\
4 \cdot 23 \\
25 \cdot 26 \\
4 \cdot 31 \\
4 \cdot 43 \\
3 \cdot 84 \\
4 \cdot 06 \\
3 \cdot 13 \\
5 \cdot 78 \\
2 \cdot 78 \\
2 \cdot 61 \\
5 \cdot 16 \\
2 \cdot 29\end{array}$ & $\begin{array}{r}7 \cdot 00 \\
2 \cdot 51 \\
4 \cdot 02 \\
27 \cdot 80 \\
1 \cdot 87 \\
4 \cdot 23 \\
2 \cdot 96 \\
2 \cdot 16 \\
2 \cdot 15 \\
5 \cdot 86 \\
2 \cdot 00 \\
2 \cdot 30 \\
4 \cdot 51 \\
2 \cdot 29\end{array}$ \\
\hline $\begin{array}{l}\text { Arginine } \\
\text { Methionine }\end{array}$ & $\begin{array}{r}11 \cdot 55 \\
I \cdot I 6\end{array}$ & $\begin{array}{r}12.40 \\
0.47\end{array}$ \\
\hline Cystine & 1.63 & 0.48 \\
\hline FDNB, fluorodinitrobenzene reactive lysine & $4 \cdot 70$ & 3.47 \\
\hline
\end{tabular}

* The part remaining after removal of gums and seed coat.

were extracted by boiling $0.5 \mathrm{~g} \mathrm{CGM}$ in $100 \mathrm{ml}$ distilled water for $30 \mathrm{~min}$ and estimated in the filtrate by the Folin-Denis colorimetric method as described in the Association of Official Analytical Chemists (1970). The proximate composition of CGM and its protein isolate and the amino acid profile are given in Table 1 .

Amino acids were determined by column chromatography using a Spinco Beckman I 20-C automatic amino acid analyzer (Beckman Instruments, Palo Alto, Calif. USA). The samples were weighed and $6 \mathrm{~m}$-hydrochloric acid added in glass-tubes frozen in liquid $\mathrm{N}_{2}$ and vacuum-sealed. The ratio of sample to hydrochloric acid was I mg sample: I ml acid and the hydrolysis continued for $24 \mathrm{~h}$ at $110^{\circ}$. The hydrolysate was then filtered and the acid removed by evaporation under reduced pressure. The residue was taken up in $6 \mathrm{ml} 0.2 \mathrm{M}-$ sodium citrate buffer, $\mathrm{pH} \mathbf{2 \cdot 2}$. For the determination of sulphur-amino acids the samples were first oxidized with performic acid for $18 \mathrm{~h}$ according to the method of Lewis (I966) before acid hydrolysis. Fluorodinitro-benzene-reactive lysine was determined by the method of Carpenter (1960) as modified by Booth (197I). All analyses were replicated and accepted with a deviation from the mean value not more than $5 \%$.

\section{Preparation of the protein isolate}

A measured quantity ( $75 \mathrm{~g}$ ) of the CGM was used, suspended in $\mathrm{I} l$ water and the $\mathrm{pH}$ adjusted to $\mathrm{I} \cdot 5$ with hydrochloric acid. The suspension was stirred for $\mathrm{I} h$ at room temperature and the supernatant fraction was separated after centrifugation ( $4000 \mathrm{~g}$ for $20 \mathrm{~min}$ ). 


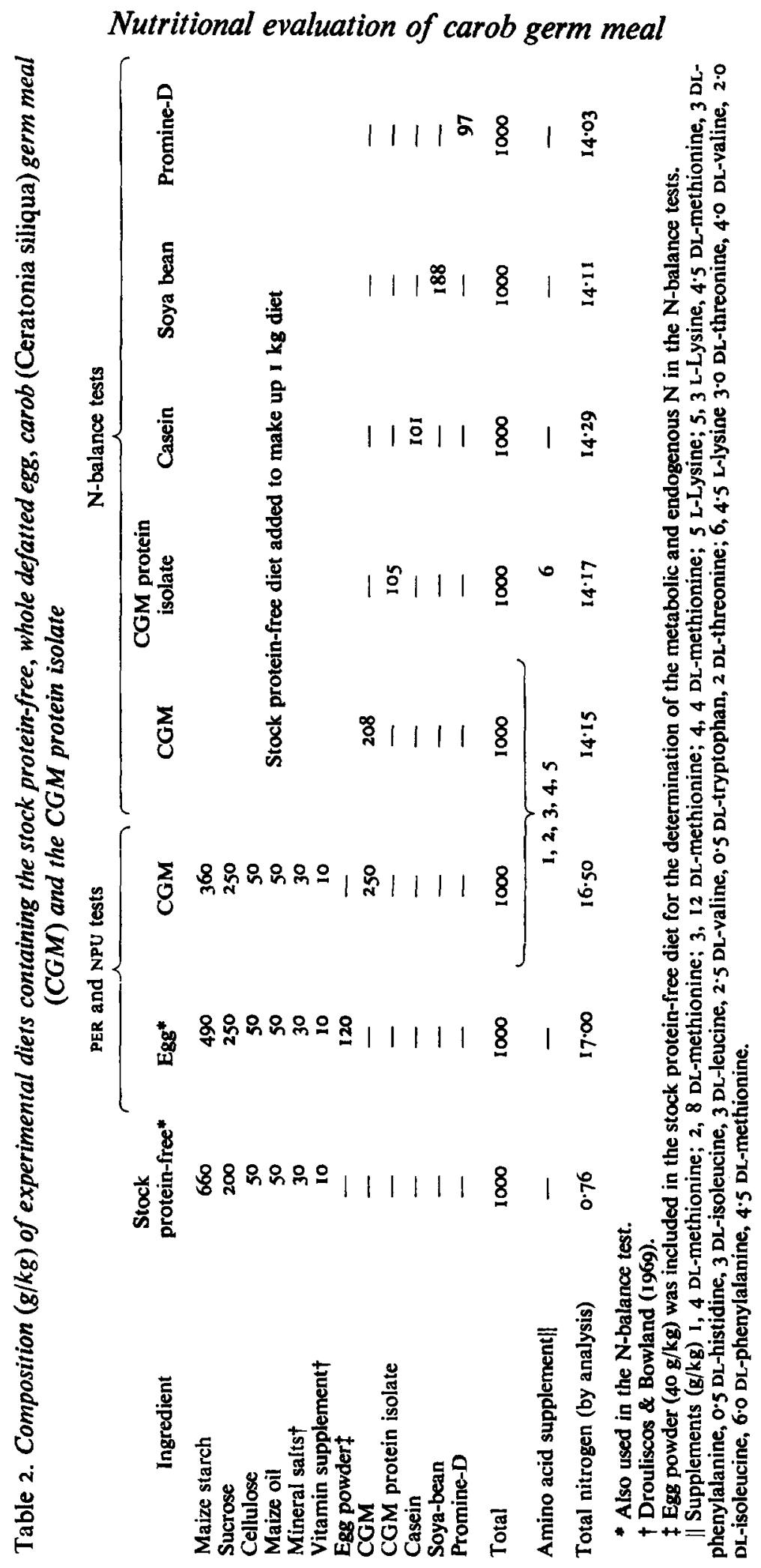


The residue was washed once with $500 \mathrm{ml}$ water and the supernatant fraction collected after centrifugation. Protein in the combined supernatant fractions was precipitated at $\mathrm{pH} 4.5$. After washing with water the protein was separated by centrifugation and freeze dried.

\section{Animals}

The rats used for the bioassays were of both sexes and of the Hooded strain weighing 45-50 $\mathrm{g}$ for PER and NPU (carcass analysis) tests and $75-80 \mathrm{~g}$ for the $\mathrm{N}$ balance study. The number of rats varied from six to ten for PER, a total of eight rats (four in each of the duplicate tests) for the NPU and four to five for the N balance. For each of the balance experiments the rats were placed in individual cages equipped for the separation of faeces and urine and the measurement of food intake. The experimental period lasted for $10 \mathrm{~d}(5 \mathrm{~d}$ preliminary and $5 \mathrm{~d}$ collection). For NPU determination the rats were caged in groups of four and the experimental period lasted for ro $\mathrm{d}$ preceded by a $5 \mathrm{~d}$ preliminary period. In the PER experiment the rats were caged individually and the experiment lasted for $28 \mathrm{~d}$. Food was offered ad lib. for PER and NPU tests and a premeasured quantity of food calculated to provide $150 \mathrm{mg} \mathrm{N}$ and $10 \mathrm{~g}$ dry matter/rat per $\mathrm{d}$ was offered to each rat for the $\mathrm{N}$ balance tests as described by Eggum (1973). All animals were maintained under controlled temperature $\left(2 \mathrm{I} \pm \mathrm{I}^{\circ}\right)$ and humidity $(55 \%)$ conditions.

Diets

The composition of the experimental diets is given in Table 2. The stock protein-free diet was mixed with the test protein to provide the required $\mathrm{N}$ and DM content for the nitrogen balance experiments.

\section{Nutritional indices}

PER was calculated from values for body-weight gain and CP intake over a $28 \mathrm{~d}$ period with a diet providing $\mathrm{I} 6 \mathrm{~g} \mathrm{~N} / \mathrm{kg}$. PER was calculated as body-weight gain/unit CP intake. In each case the figures of CP intake used for the calculation of PER, $N$ balance and NPU were based on actual nitrogen analysis of the test diets. NPU was calculated from information on carcass composition with a protein-free and a test diet.

The procedure followed was as described by Bender \& Miller (1953) and Miller \& Bender (1955). The $\mathrm{N}$ balance trials were carried out according to the procedures followed by Eggum (1973). Metabolic and endogenous $\mathbf{N}$ were determined separately with a protein-free diet in several replicates (four runs with 21 rats) and the mean values were used in the determination of $\mathrm{BV}$ and true digestibilities (TD).

\section{RESULTS AND DISCUSSION}

Analysis of CGM (Table 1 ) indicated that the CP content of $426 \mathrm{~g} / \mathrm{kg}$ is at a level comparable to that of the soya-bean meal (SOM-45, $457 \mathrm{~g} / \mathrm{kg}$ ) (Drouliscos, 1976) and certain other protein-rich vegetable concentrates.

The amino acid profile of CGM (Table I) suggests that methionine and cystine are first limiting. The remaining amino acids were also present at levels that were somewhat lower than those recommended in the FAO/WHO pattern (Table 3). In comparison with the FAO/WHO amino acid pattern CGM and CGM protein isolate contain insufficient leucine, isoleucine, threonine and valine. Arginine is exceptionally high in CGM (II.55 g/16 $\mathrm{g} \mathrm{N}$ ) and CGM protein isolate ( $12.40 \mathrm{~g} / 16 \mathrm{~g} \mathrm{~N}$ ). A high arginine content (I I.24 g/16 g N) was also reported by Ferreira (I964). When the values of essential amino acids (Table 4 ) were expressed as essential amino acid content: $N$ content, the value for CGM $(2 \cdot 56)$ was higher than that of the CGM protein isolate $(2 \cdot 18)$ but lower than those of the soya-bean protein isolate (Promine-D) $(2 \cdot 68)$, SOM $-45(2 \cdot 80)$, casein $(3 \cdot 28)$ and whole defatted egg 
Table 3. Essential amino acid $(A A)$ pattern $(g A A / 16 g N)$ and amounts of each $A A$ provided by carob (Ceratonia siliqua) germ meal $(C G M)^{*}$ and $C G M$ protein isolate

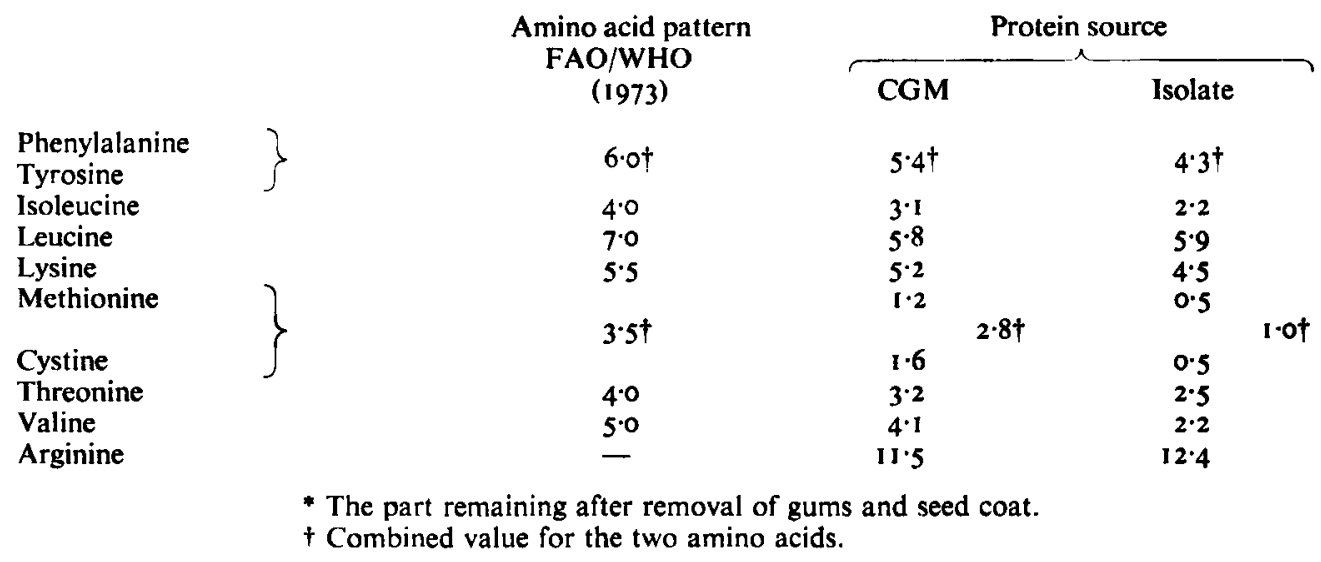

(3.40). Table 5 shows an inverse relationship between urinary $\mathrm{N}$ excretion $(\mathrm{g} / \mathrm{kg}$ metabolic body size) $\left(W^{0.75}\right)$ and $B v$. The lowest value of urinary $N$ excretion $\left(0.86 \mathrm{~g} / \mathrm{kg} \mathrm{W}^{0.75}\right)$ was recorded for whole defatted egg and the highest $\left(2.69 \mathrm{~g} / \mathrm{kg} \mathrm{W}^{0.75}\right)$ for CGM protein isolate, corresponding to BV values of 0.93 and 0.36 respectively. The faecal $\mathrm{N}$ excretion remained at fairly constant levels $\left(0.37-0.48 \mathrm{~g} / \mathrm{kg} \mathrm{W}^{0.75}\right)$ with the exception of SOM-45 $\left(0.95 \mathrm{~g} / \mathrm{kg} \mathrm{W} \mathrm{W}^{0.75}\right)$ and CGM $\left(1 \cdot 17 \mathrm{~g} / \mathrm{kg} \mathrm{W}^{0.75}\right)$. This discrepancy might be explained on the grounds of productpurity since SOM-45 and CGM are not pure proteins and contain other material such as celluloses, hemicelluloses, pentosans, phenolic compounds and other organic substances. The excess $\mathrm{N}$ that appeared in the faeces with SOM-45 and CGM may have been due to an undigested portion of protein encapsulated in a fibrous coating within the plant tissue and so protected from the proteolytic enzymes of the gut (Drouliscos \& Bowland 1969). It is also likely that in the CGM protein was precipitated due to the presence of the phenolic compounds.

The results recorded with feeding trials with rats show that at a level of inclusion of CGM in the diet of $250 \mathrm{~g} / \mathrm{kg}$ the PER and NPU values were $\mathrm{I} \cdot 66$ and 0.58 compared with those recorded for dried tomato pomace (PER 2.I8 NPU 0.55) (Drouliscos, 1976) and SOM-45 (PER 2.40 NPU 0.80) (Drouliscos \& Bowland, I969).

Supplementation with DL-methionine at 4 and $8 \mathrm{~g} / \mathrm{kg}$ diet elicited a growth response but further addition $(12 \mathrm{~g} / \mathrm{kg}$ ) had a depressing effect on growth, protein intake and $\mathrm{Bv}$ (Table 6).

The addition of other essential amino acids improved growth, PER and BV, indicating a deficiency or an imbalance in the protein provided by the CGM (supplements 4 and 5) Table 6. Biological values were restored with supplements 4 and $5(0.79$ and 0.78$)$ to the level recorded with supplement $\mathrm{I}(0.80)$ (Table 6). This response is indicative of a methionine deficiency since the inclusion of lysine in supplement 4 and of isoleucine, histidine and other essential amino acids in supplement 5 (Table 2) had no effect on the BV value. It is therefore likely that under the present experimental conditions methionine was the most limiting amino acid followed by leucine, isoleucine and threonine as second limiting. It could be of interest to see the response to leucine and isoleucine supplementation without methionine. This was not done in this study. Accordingly the value of PER of unsupplemented CGM was improved by $34.9 \%$ by supplement 4 and $56 \%$ by supplement 5 (Table 6). This suggests that the response in growth and PER was the result of the extra $\mathbf{N}$ intake (Table 6). It is not surprising that the lowest $\mathrm{BV}$ and NPU (by $\mathrm{N}$ balance) values 


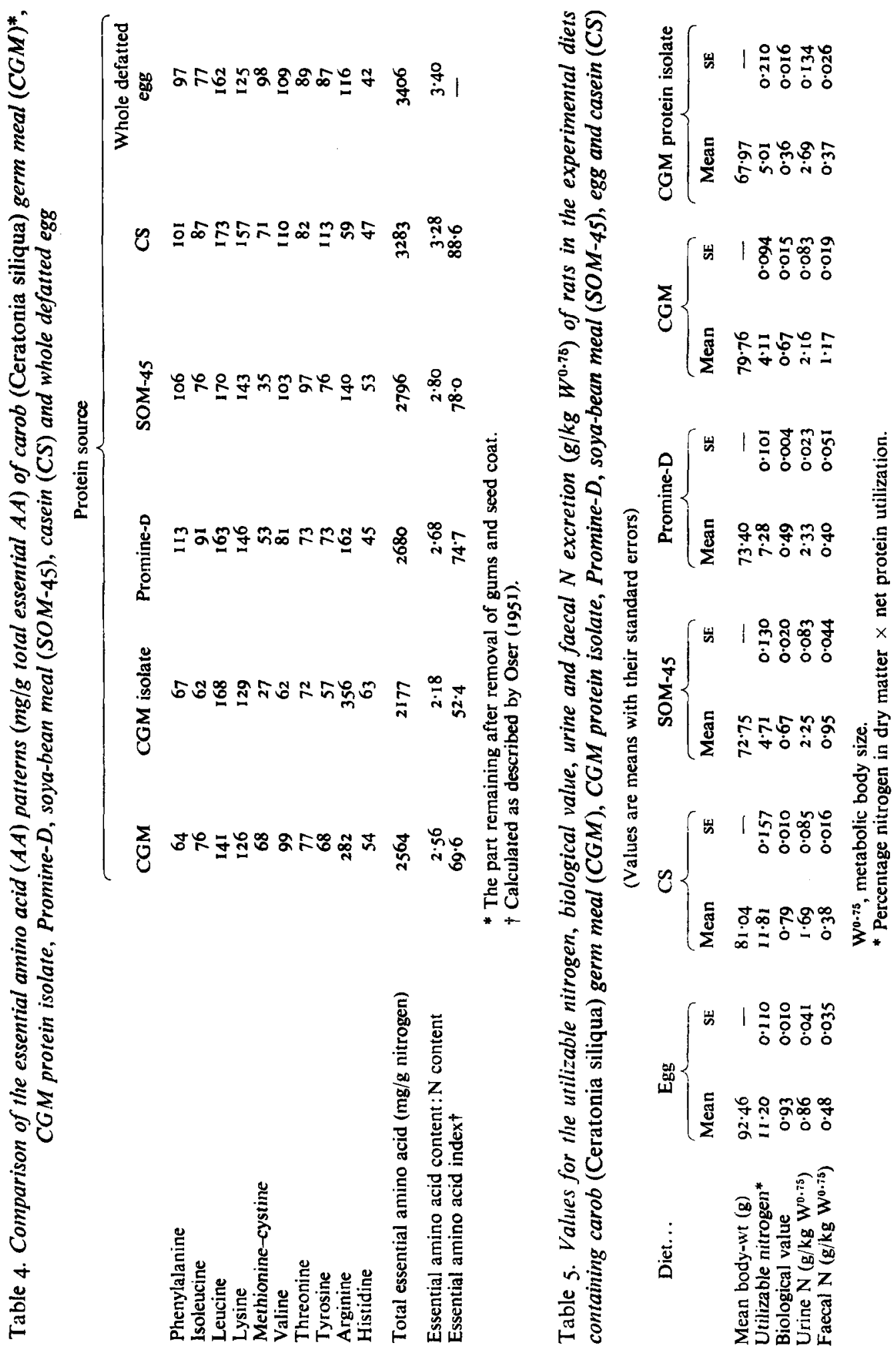




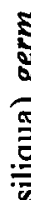

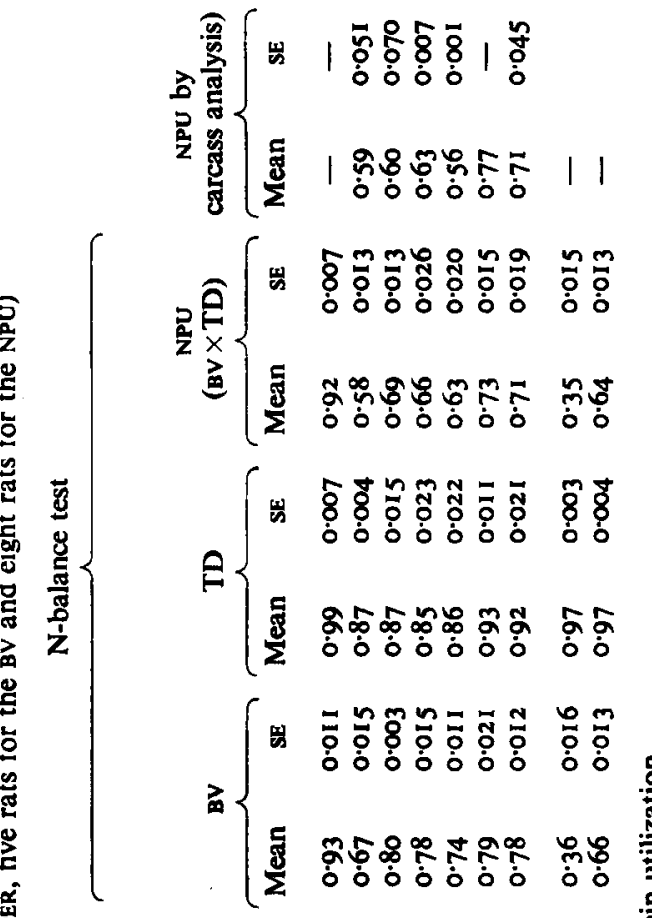

总

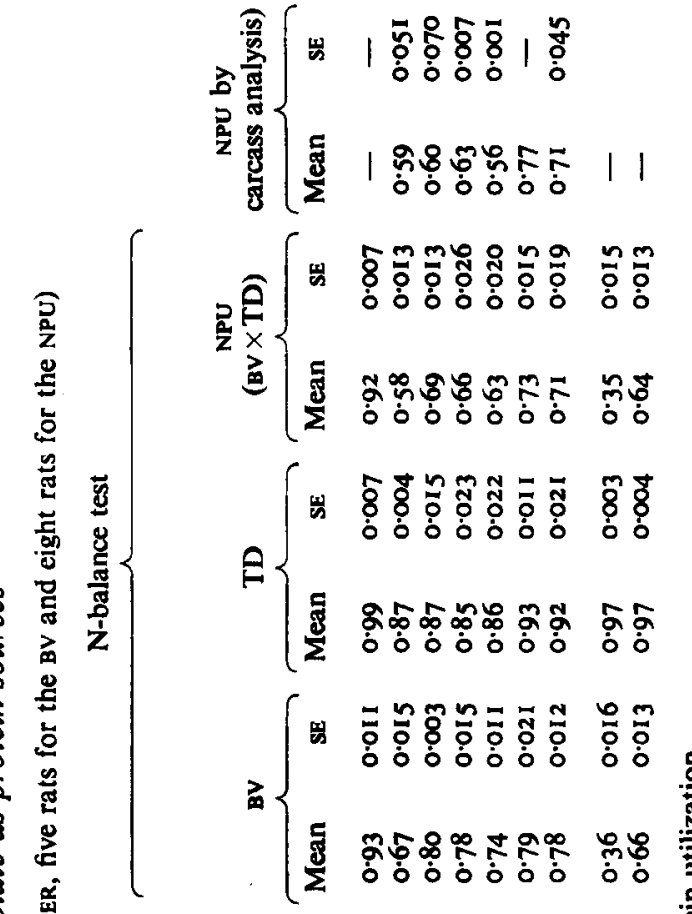

窇

愛

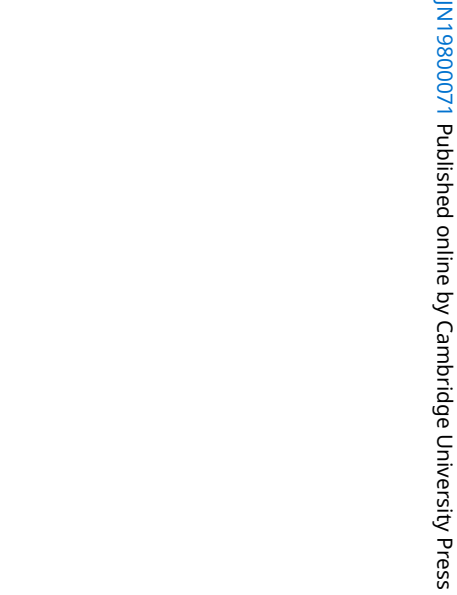

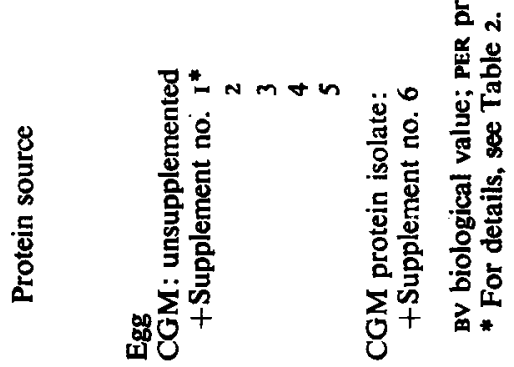


were recorded for CGM protein isolate (BV 0.36, NPU 0.35) (Table 6) since as shown in Table I the methionine and cystine content is one-third of the value recorded for the CGM. Supplementation of CGM protein isolate with methionine and other amino acids (supplement 6; Table 2) raised the BV value to $0 \cdot 66$. Due to the limited quantity of the isolate that was available for the bioassays the PER was not carried out. The poor performance of CGM protein isolate as judged by the low NPU $(0.35)$ is in close agreement with values reported by Shemer \& Perkins (1974) for soya-bean protein isolate (Promine-D), the range was 0.24-0.36.

It is interesting to note that in the present study the BV obtained with Promine-D was 0.49 (Table 5) with value for NPU (BV $\times$ TD) of 0.47 . This value is higher than the value of 0.29 reported by Shemer \& Perkins (1974) for Promine-D. The recorded value could have been due to the heavier and older rats used for the NPU determination resulting in lower $\mathbf{N}$ retention.

On the basis of the previously mentioned observations some conclusions may be drawn regarding the protein quality of CGM and its isolate. With CGM used in the present study at $250 \mathrm{~g} / \mathrm{kg}$ diet to supply all the protein, growth in rats was $43.4 \%$ of that with the egg diet. The addition of amino acids (supplements nos. 1, 2, 4 and 5, Table 2) progressively improved body-weight gain to a maximum of $97.4 \%$ (Table 6). Supplement no. 3 ( 12 g DL-methionine/ $\mathrm{kg}$ ) reduced growth and protein intake (Table 6 ) suggesting that the methionine added was in excess and could have created an amino acid imbalance or a slight toxicity. Similar observations have been reported by Drouliscos (1976) with dry tomato pomace supplemented with $5 \mathrm{~g}$ methionine $/ \mathrm{kg}$ diet in rats, by Muramatsu et al. (I97I) with the addition of $50 \mathrm{~g}$ methionine $/ \mathrm{kg}$ diet in rats and by Smith et al. (1975) with $2 \mathrm{~g}$ methionine $/ \mathrm{kg}$ diet (Aspergillus oryzae biomass) in pigs.

CGM could replace part of the protein portion of a compounded feed for single-stomached species provided its amino acid deficiencies are corrected. Experiments with broiler chicks are in progress and the observations made will be reported in a later communication.

There appears to be some indication that during the preparation of the protein isolate under the experimental conditions of this study a certain loss of the sulphur containing amino acids is taking place together with some other essential amino acids such as lysine, valine, threonine and isoleucine (Table I).

It should therefore be pointed out that although isolates appear to have a high CP content, they may not necessarily be well balanced in terms of their amino acid composition.

It is in this context that the incorporation of such products in various food preparations should be carefully planned and the required amino acids added if necessary.

This study was partly supported by a grant of the National Research Foundation. The authors thank Dr B. Macris for the preparation of the carob germ isolate and Miss I. Siganou for laboratory assistance.

\section{RERERENCES}

Association of Official Analytical Chemists (1970). Official Methods of Analysis, i th ed. Washington, DC: Association of Official Analytical Chemists.

Bender, A. E. \& Miller, D. S. (1953). Biochem. J. 53, VII.

Booth, V. H. (1971). J. Sci. Fd Agric. 22, 658.

Carpenter, K. J. (1960). Biochem. J. 77, 604.

Drouliscos, N. J. (I976). Br. J. Nutr. 36, 449.

Drouliscos, N. J. \& Bowland, J. P. (I 969). Br. J. Nutr. 23, I 13.

Eggum, B. O. (1973). Bereth. Forsogslab. no. 406.

FAO/WHO. (1973). Geneva, Tech. Rep. Ser. Wld Hlth Org. no. 522. Geneva: WHO.

Ferreira, M. F. (1964). Bolm pecuár. 32, 5.

Lewis, O. A. H. (1966). Nature, Lond. $209,1239$.

Miller, D. S. \& Bender, A. E. (I955). Br. J. Nutr. 9, 382. 
Maramatsu, K., Odagiri, H., Morishita, S. \& Takeuchi, H. (1971). J. Nutr. ror, 1 I 17.

National Research Council (1962). Publs natn. Res. Coun. Wash., no. 990.

Oser, B. L. (1951). J. Am. diet. Ass. 27, 396.

Shemer, M. \& Perkins, E. G. (1974). J. Nutr. 104, 1389.

Smith, R. H., Palmer, R. A. \& Reade, A. E. (1975). J. Sci. Fd Agric. 26, 785. 